\title{
PENERAPAN MODEL PEMBELAJARAN KOOPERATIF TIPE STUDENT TEAMS ACHIEVEMENT DIVISIONS (STAD) DALAM MENINGKATKAN HASIL BELAJAR PKN KELAS IV SDN 2 MALA-MALA
}

\author{
Retno Dewi Sari ${ }^{1)}$, Sakka Hasan ${ }^{2)}$ \\ ${ }^{1)}$ SDN 2 Mala-Mala, Kolaka Utara, Indonesia \\ ${ }^{2)}$ Jurusan PGSD, Universitas Halu Oleo, Kendari, Indonesia \\ email:retnodewisarii.pji@gmail.com
}

\begin{abstract}
Abstrak:Tujuan dari penelitian ini adalah untuk meningkatkan hasil belajar PKn siswa pada materi Pemerintahan desa dan kecamatan melalui penerapan model pembelajaran kooperatif tipe STAD di kelas IV SD Negeri 2 Mala-Mala. Prosedur penelitian yaitu; (a) perencanaan (planning), (b) pelaksanaan tindakan (action), (c) observasi dan evaluasi (observation and evaluation), dan (d) refleksi (reflection). Jenis data yaitu data kualitatif dan data kuantitatif. Data kualitatif diperoleh melalui lembar observasi sedangkan data kualitatif melalui tes hasil belajar. Hasil analisis penelitian menunjukkan bahwa pada siklus I ketuntasan hasil belajar siswa mencapai 73,33\% dengan nilai rata-rata 70,67 dan pada siklus II mencapai sebesar 93,33\% dengan nilai rata-rata 77,33. Aktivitas siswa pada siklus I pertemuan pertama yang mencapai $66,67 \%$ dan pertemuan kedua mencapai $77,78 \%$ meningkat pada siklus II pertemuan pertama mencapai $88,89 \%$ dan pertemuan kedua mencapai $100 \%$. Aktivitas guru pada siklus I pertemuan pertama yang mencapai $66,67 \%$ dan pertemuan kedua mencapai $75 \%$ meningkat pada siklus II pertemuan pertama mencapai $91,67 \%$ dan pertemuan kedua mencapai $100 \%$.
\end{abstract}

Kata kunci: Model pembelajaran; STAD; hasil belajar.

\section{APPLICATION OF STUDENT TEAMS ACHIEVEMENT DIVISIONS (STAD) COOPERATIVE LEARNING MODELS IN IMPROVING PKN LEARNING RESULTS IN CLASS IV SDN 2 MALA-MALA}

\begin{abstract}
The purpose of this study was to improve student civics learning outcomes in village and sub-district government materials through the application of the STAD type cooperative learning model in class IV SD Negeri 2 Mala-Mala. Research procedures, namely; (a) planning, (b) action, (c) observation and evaluation, and (d) reflection. Types of data are qualitative data and quantitative data. Qualitative data were obtained through observation sheets, while qualitative data were obtained through learning outcomes tests. The results of the research analysis showed that in the first cycle the completeness of student learning outcomes reached $73.33 \%$ with an average value of 70.67 and in the second cycle it reached $93.33 \%$ with an average value of 77.33. Student activity in the first cycle of the first meeting reached $66.67 \%$ and the second meeting reached $77.78 \%$, increasing in the second cycle the first meeting reached $88.89 \%$ and the second meeting reached 100\%. Teacher activity in the first cycle of the first meeting reached $66.67 \%$ and the second meeting reached $75 \%$, increasing in the second cycle the first meeting reached $91.67 \%$ and the second meeting reached $100 \%$.
\end{abstract}

Key words: learning model; STAD; learning outcomes. 


\section{Pendahuluan}

Dalam dunia pendidikan paradigma lama mengenai proses belajar mengajar bersumber pada teori (atau lebih tepatnya asumsi) tabula rasa John Locke yang menyatakan bahwa pikiran anak seperti kertas kosong yang putih dan siap menunggu coretan-coretan gurunya. Dengan kata lain, otak seorang anak sepeti botol kosong yang siap diisi dengan segala ilmu pengetahuan dan kebijaksanaan sang guru.

Tuntutan dalam dunia pendidikan sudah banyak berubah. Kita tidak bisa lagi mempertahankan paradigma lama tersebut. Teori, penelitian dan pelaksanaan kegiatan belajar mengajar membuktikan bahwa para guru sudah harus mengubah paradigma pengajaran. Kita perlu menelaah kembali praktik-praktik pembelajaran di sekolah-sekolah. Peranan yang harus dimainkan oleh dunia pendidikan dalam mempersiapkan anak didik untuk berpartisipasi secara utuh dalam kehidupan bermasyarakat sangat berbeda dengan peranan tradisional yang selama ini dipegang oleh sekolah-sekolah.

Ada persepsi umum yang sudah berakar dalam dunia pendidikan juga sudah menjadi harapan masyarakat. Persepsi umum ini menganggap bahwa sudah merupakan tugas guru untuk mengajar dan menyodori siswa dengan muatan-muatan informasi dan pengetahuan. Guru perlu bersikap atau setidaknya dipandang oleh siswa sebagai yang mahatahu dan sumber informasi. Lebih celaka lagi siswa belajar dalam situasi yang membebani dan menakutkan karena dibayangi oleh tuntutan-tuntutan mengajar nilai-nilai tes dan ujian yang tinggi.

Hasil observasi di kelas pada saat guru mengajar siswa kelas IV, menunjukan bahwa sebagian besar siswanya cenderung pasif dalam kegiatan pembelajaran. Selama kegitan pembelajaran, siswa jarang sekali mengajukan pertanyaan, gagasan ataupun menanggapi pertanyaan serta kurang mampu untuk bekerjasama dalam kelompok. Siswa juga kurang termotivasi untuk mengerjakan tugas yang diberikan oleh guru sehingga pada akhir pembelajaran tidak menampakkan adanya peningkatan hasil belajar yang mengakibatkan aspek kognitif siswa masih berada dibawah standar rata-rata. Hal ini dapat dilihat dari nilai ulangan semester ganjil mata pelajaran PKn materi Pemerintahan desa dan kecamatan yang diperoleh siswa SD Negeri 2 Mala-Mala kelas IV dengan jumlah siswa 21 orang terdiri dari 8 orang perempuan dan 13 orang laki-laki pada semester ganjil Tahun Ajaran 2015/2016 menunjukan bahwa hasil belajar yang dicapai siswa pada mata pelajaran Pendidikan Kewarganegaraan (PKn) tergolong masih rendah yaitu 64,44 karena belum mencapai nilai kriteria ketuntasan minimal (KKM) yang ditetapkan oleh sekolah yaitu 70 sehingga perlu mengikuti remedial.

Tampaknya perlu adanya perubahan dalam menelaah proses belajar siswa interaksi antara siswa dan guru. Sudah seyogyanya kegiatan belajar mengajar juga lebih mempertimbangkan siswa. Siswa bukanlah sebuah botol kosong yang bisa diisi dengan muatan-muatan informasi apa saja yang dianggap perlu oleh guru. Selain itu, alur proses belajar tidak harus berasal dari guru menuju siswa. Siswa bisa juga saling mengajar dengan sesama siswa yang lainnya. Bahkan banyak penelitian menunjukkan bahwa pengajaran oleh rekan sebaya (pear teaching) ternyata lebih efektif daripada pengajaran oleh guru. Sistem pengajaran yang memberi kesempatan kepada anak didik untuk bekerjasama dengan sesama siswa dalam tugas-tugas yang terstruktur disebut sebagai sistem "pembelajaran gotong royong" atau cooperative learning. Dalam sistem ini, guru bertindak sebagai fasilitator.

Metode pembelajaran kooperatif distruktur sedemikian rupa sehingga masing-masing anggota dalam satu kelompok melaksanakan tanggung jawab pribadinya karena ada sistem akuntabilitas individu. Siswa tidak bisa begitu saja membonceng jerih payah rekannya dan usaha setiap siswa akan dihargai sesuai dengan poin-poin perbaikannya. Adapun langkahlangkah pembelakaran STAD adalah: 1) guru menyampaikan pembelajaran dan memotivasi siswa; 2) guru mrnyampaikan materi; 3) guru mengorganisasikan siswa ke dalam kelompok; 
4) guru membimbing siswa dikelompok kecil; 5) guru memberikan tes kepada siswa secara individual; 6) guru memberikan penghargaan kepada siswa (Tipa, D.S.R. dkk. 2016)

Dari latar belakang masalah tersebut, maka peneliti merasa terdorong untuk melihat pengaruh pembelajaran kooperatif tipe STAD terhadap hasil belajar siswa dengan mengambil judul "Penerapan Model Pembelajaran Kooperatif Tipe Student Teams Achievement Divisions (STAD) dalam Meningkatkan Hasil Belajar PKn Materi Pemerintahan Desa dan Kecamatan pada Siswa Kelas IV SD Negeri 2 Mala-Mala Kabupaten Kolaka Utara”.

Penelitian yang dilakukan Syafangah, I.A. ddk. (2015) penggunaan metode pembelajaran kooperatif tipe STAD dapat meningkatkan aktivitas dan ketuntasan belajar siswa kelas XI MIA 3 SMA Negeri 2 Magelang. Penelitian yang dilakukan Utami, S.(2015) Pada siklus pertama rerata nilai ulangan harian siswa sebesar 7,06 dan rerata nilai ulangan harian pada siklus kedua sebesar 5,9 sedangkan rerata nilai di siklus ketiga sebesar 7.09. Dari hasil penelitian tersebut maka dapat disimpulkan bahwa pembelajaran kooperatif tipe STAD mampu meningkatkan hasil belajar siswa hingga memenuhi Kriteria Ketuntasan Minimal (KKM).

Model Pembelajaran Student Teams Achievement Divisions dirancang secara matang dan dilaksanakan secara tepat diharapkan dapat mendorong siswa lebih dapat meningkatkan persiapan dalam menerima pelajaran. Peningkatan motivasi belajar siswa juga diharapkan membawa dampak positif yaitu peningkatan hasil belajar siswa.

Masalah dalam penelitian adalah apakah penerapan model pembelajaran kooperatif tipe STAD dapat meningkatkan hasil belajar PKn materi pemerintahan desa dan kecamatan pada siswa kelas IV SD Negeri 2 Mala-Mala??. Tujuan penelitian adalah untuk meningkatkan hasil belajar PKn siswa pada materi Pemerintahan desa dan kecamatan melalui penerapan model pembelajaran kooperatif tipe STAD di kelas IV SD Negeri 2 Mala-Mala. Penelitian ini diharapkan dapat memberikan manfaat bagi guru, siswa, sekolah dan penelitian lainnya.

\section{Metode}

Jenis penelitian ini adalah penelitian tindakan kelas (PTK). Penelitian ini adalah suatu bentuk kajian yang bersifat reflektif oleh pelaku tindakan. Dalam prosedur pelaksanaannya dilakukan dengan proses pengkajian berdaur yang terdiri dari empat tahap: perencanaan, pelaksanaan tindakan, observasi dan evaluasi serta refleksi (Kurniasih dan Sani, 2014:3). Penelitian ini dilaksanakan di SD Negeri 2 Mala-Mala pada kelas IV semester ganjil tahun ajaran 2016/2017 yang dilaksanakan dalam dua siklus, tiap siklus terdiri dari dua kali pertemuan. Subjek penelitian ini adalah guru dan siswa di kelas IV SD Negeri 2 Mala-Mala yang berjumlah 15 siswa, terdiri dari 7 orang laki-laki dan 8 orang perempuan. Faktor yang diteliti dalam penelitian ini adalah 1) faktor siswa, 2) Faktor guru dan faktor 3) hasil belajar. Penelitian Tindakan Kelas ini dilaksanakan dalam 2 (dua) siklus. Adapun prosedur penelitian tindakan ini meliputi: (1) Perencanaan, (2) Pelaksanaan Tindakan, (3) Observasi dan Evaluasi, dan (4) Refleksi dalam setiap siklus. Jenis data yaitu data kualitatif dan data kuantitatif. Data kualitatif diperoleh melalui observasi, menggunakan lembar observasi sedangkan data kuantitatif diperoleh melalui tes setiap akhis siklus tindakan

Jenis data dalam penelitian ini adalah data kualitatif dan kuantitatif. Data kualitatif berupa kegiatan proses pembelajaran aktivitas belajar siswa dan aktivitas guru sedangkan data kuantitatif berupa nilai hasil belajar siswa.

Data yang diperoleh dalam penelitian ini dianalisis dengan menggunakan analisis deskriptif dengan cara menghitung jumlah skor hasil observasi, selanjutnya dihitung persentasenya yang dimaksudkan untuk memberikan gambaran distribusi hasil belajar siswa.

Indikator kinerja dalam penelitian ini adalah 1) Indikator kinerja yang berkaitan dengan peningkatan hasil belajar siswa yaitu jika minimal $80 \%$ siswa telah memperoleh nilai 
minimal 70, 2) Indikator kinerja yang berkaitan dengan keberhasilan pelaksanaan pembelajaran dengan menerapkan model pembelajaran kooperati tipe STAD yaitu minimal $80 \%$ dari skenario/langkah-langkah pembelajaran yang termuat dalam RPP yang telah dilaksanakan dengan baik.

\section{Hasil}

1. Hasil Belajar Siswa

Hasil analisis penelitian menunjukkan bahwa pada siklus I ketuntasan hasil belajar siswa mencapai $73,33 \%$ dengan nilai rata-rata 70,67 dan pada siklus II mencapai sebesar 93,33\% dengan nilai rata-rata 77,33.

\section{Aktivitas Mengajar Guru}

Aktivitas guru pada siklus I pertemuan pertama yang mencapai $66,67 \%$ dan pertemuan kedua mencapai $75 \%$ meningkat pada siklus II pertemuan pertama mencapai 91,67\% dan pertemuan kedua mencapai $100 \%$.

3. Aktivitas Belajar Siswa

Aktivitas siswa pada siklus I pertemuan pertama yang mencapai $66,67 \%$ dan pertemuan kedua mencapai $77,78 \%$ meningkat pada siklus II pertemuan pertama mencapai $88,89 \%$ dan pertemuan kedua mencapai $100 \%$.

\section{Pembahasan}

\section{Hasil Belajar Siswa}

Hasil belajar PKn siswa pada materi pemerintahan desa dan kecamatan setelah diterapkan model pembelajaran kooperatif tipe STAD mengalami peningkatan. Untuk melihat peningkatan jumlah dan persentase siswa yang tuntas dan yang tidak tuntas dari sikuls I sampai siklus II disajikan pada gambar 1 berikut:

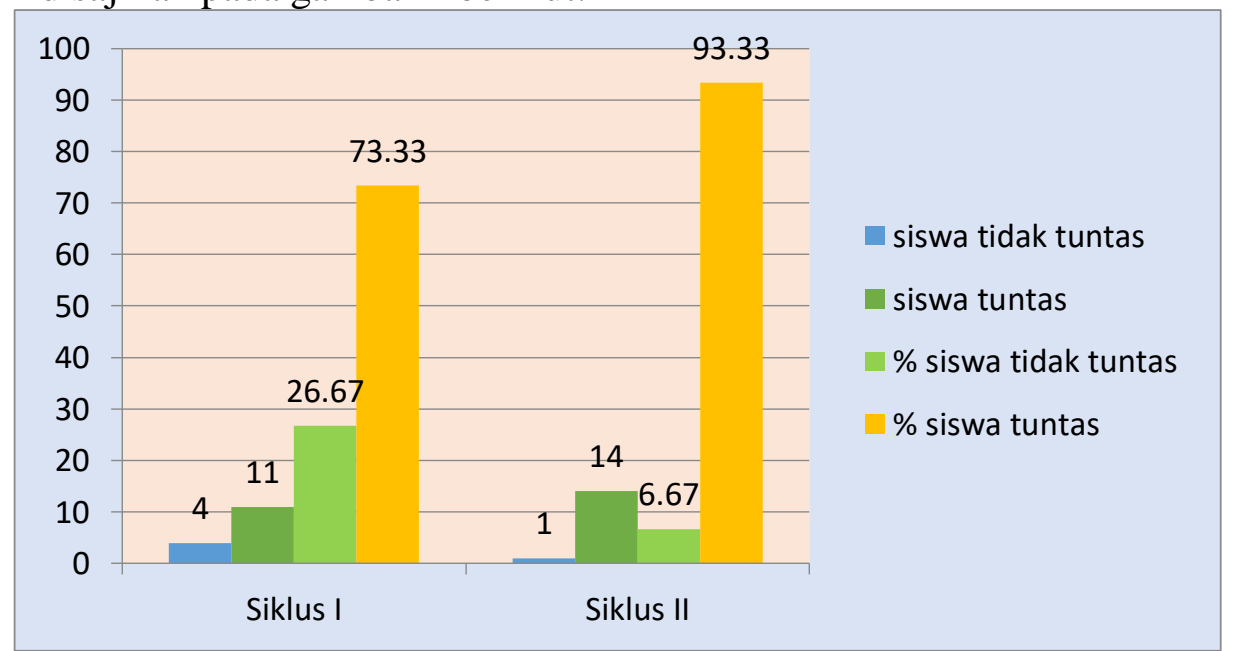

Gambar 1 Grafik Ketuntasan Hasil Belajar PKn Siswa

Berdasarkan gambar 1, menunjukkan bahwa ketuntasan hasil belajar secara klasikal pada siklus I mencapai 66,67\% atau sebanyak 11 siswa dari 15 yang tuntas belajar dan pada siklus II mengalami peningkatan mencapai 93,33\% atau sebanyak 14 siswa dari 15 siswa yang tuntas telah memperoleh nilai $\geq 70$.

Dengan melihat hasil belajar siswa pada tindakan siklus II sudah menunjukkan hasil yang cukup memuaskan, meskipun masih ada beberapa siswa belum seperti yang diharapkan, siswa juga pada proses pembelajaran sudah menunjukkan sikap positif terhadap model pembelajaran kooperatif tipe STAD karena indikator keberhasilan dalam penelitian ini telah tercapai. 
2. Aktivitas mengajar guru

Keberhasilan aktivitas mengajar guru juga menunjukkan peningkatan dari pelaksanaan siklus I dibandingkan pada pelaksanaan tindakan siklus II setelah penerapan model pembelajaran kooperatif tipe STAD. Peningkatan keberhasilan aktivitas sis wa dapat dilihat pada gambar 2 berikut:

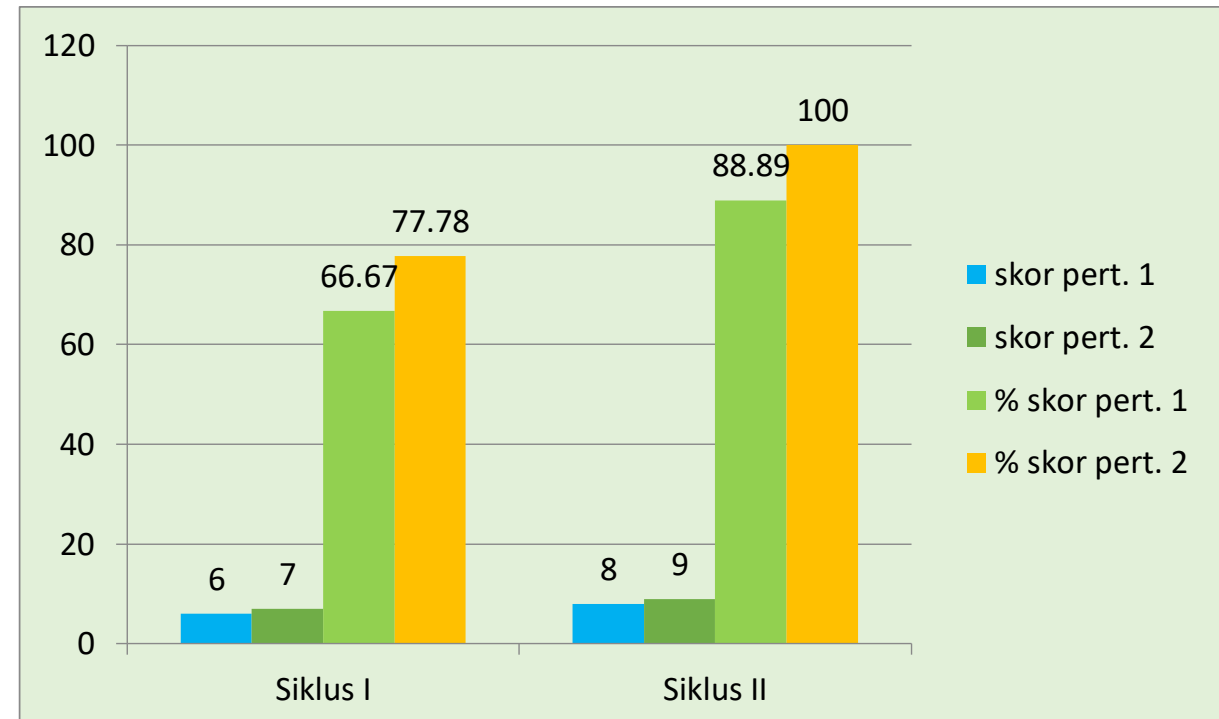

\section{Gambar 2. Grafik Peningkatan Keberhasilan Aktivitas Mengajar Guru}

Berdasarkan gambar 4.3, menunjukkan bahwa pada siklus I, keberhasilan aktivitas mengajar guru pertemuan pertama mencapai $66,67 \%$ sedangkan pertemuan kedua mencapai $77,78 \%$ dan pada siklus II pertemuan pertama keberhasilan aktivitas mengajar guru meningkat menjadi $88,89 \%$ dan pertemuan sebesar $100 \%$.

Ketuntasan belajar siswa mengindikasikan bahwa indikator keberhasilan penelitian yang ditetapkan telah tercapai. Sedangkan hasil observasi terhadap pelaksanaan pembelajaran bisa dikatakan sempurna, yakni seluruh komponen dalam skenario pembelajaran telah dilaksanakan dengan baik sesuai yang diharapkan. Karena kedua indikator telah tercapai, maka hipotesis tindakan telah tercapai yakni: penerapan model pembelajaran kooperatif tipe STAD dapat meningkatkan hasil belajar PKn siswa pada materi pemerintahan desa dan kecamatan di kelas IV SD Negeri 2 Mala-Mala Kabupaten Kolaka Utara.

3. Aktivitas Belajar Siswa

Keberhasilan aktivitas belajar siswa menunjukkan peningkatan dari pelaksanaan siklus I dibandingkan pada pelaksanaan tindakan siklus II. Peningkatan keberhasilan aktivitas siswa dapat dilihat pada gambar 3 berikut: 


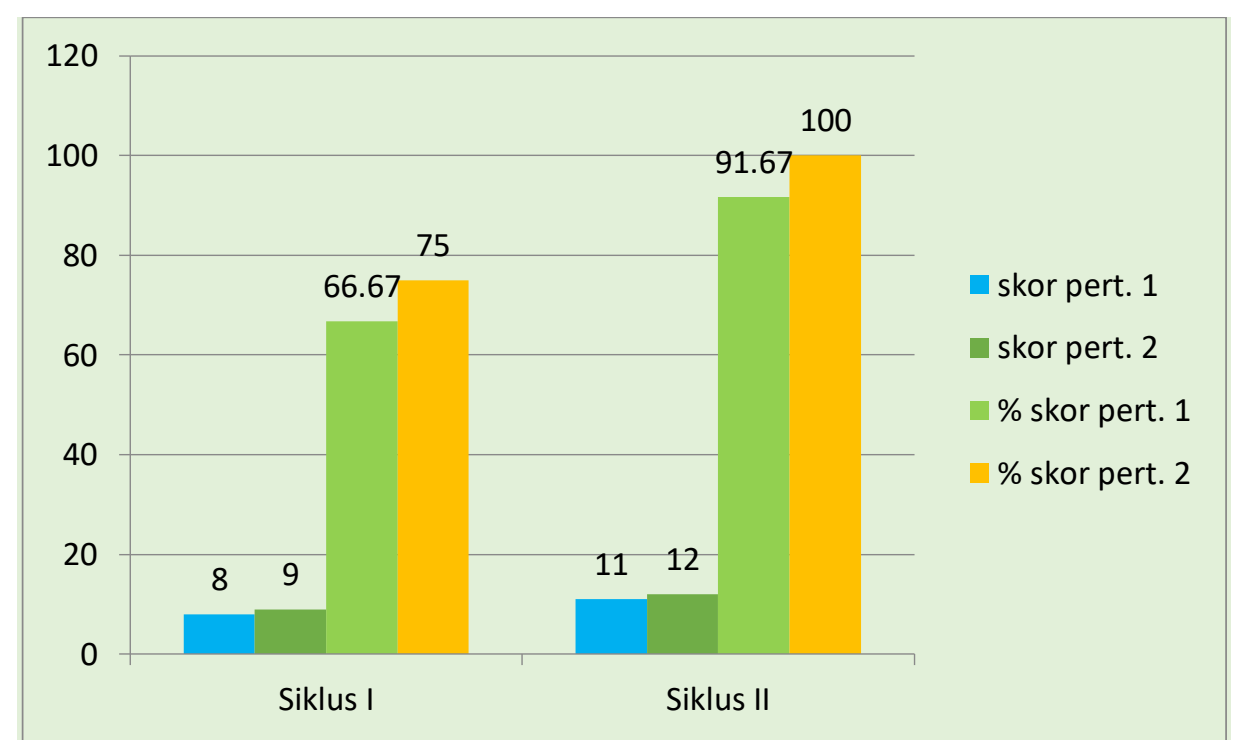

\section{Gambar 3. Grafik Peningkatan Keberhasilan Aktivitas Belajar Siswa}

Berdasarkan gambar 4.2, pada siklus I pertemuan pertama keberhasilan aktivitas belajar siswa sebesar $66,67 \%$ sedangkan pertemuan kedua sebesar $75 \%$ dan mengalami peningkatan pada siklus II pertemuan pertama sebesar 91,67\% dan pertemuan kedua sebesar $100 \%$, sehingga ketuntasan aktivitas belajar siswa pada siklus II telah tercapai.

\section{Simpulan}

1. Penerapan model pembelajaran kooperatif tipe Student Team Achievement Division (STAD) dapat meningkatkan aktivitas mengajar guru pada materi pemerintahan desa dan kecamatan di Kelas IV SD Negeri 2 Mala-Mala Kabupaten Kolaka Utara. Hal ini terlihat dari persentase aktivitas mengajar guru pada siklus I pertemuan pertama yang mencapai $66,67 \%$ dan pertemuan kedua mencapai $75 \%$ meningkat pada siklus II pertemuan pertama mencapai $91,67 \%$ dan pertemuan kedua mencapai $100 \%$.

2. Penerapan model pembelajaran kooperatif tipe Student Team Achievement Division (STAD) dapat meningkatkan aktivitas belajar siswa pada materi pemerintahan desa dan kecamatan di Kelas IV SD Negeri 2 Mala-Mala Kabupaten Kolaka Utara. Hal ini terlihat dari persentase aktivitas belajar siswa pada siklus I pertemuan pertama yang mencapai $66,67 \%$ dan pertemuan kedua mencapai $77,78 \%$ meningkat pada siklus II pertemuan pertama mencapai $88,89 \%$ dan pertemuan kedua mencapai $100 \%$.

3. Penerapan model pembelajaran kooperatif tipe Student Team Achievement Division (STAD) dapat meningkatkan hasil belajar PKn siswa pada materi pemerintahan desa dan kecamatan di Kelas IV SD Negeri 2 Mala-Mala Kabupaten Kolaka Utara. Hal ini terlihat dari ketuntasan hasil belajar siswa pada siklus I yang mencapai 11 siswa atau sebesar $73,33 \%$ dengan nilai rata-rata 70,67 dan pada siklus II ketuntasan hasil belajar siswa mencapai 14 siswa atau sebesar 93,33\% dengan nilai rata-rata 77,33. 


\section{Referensi}

Kurniasih dan Sani. 2014. Implementasi Kurikulum 2013. Konsep dan Penerapan. Surabaya: Kata Pena.

Syafangah, I.A. dkk. 2015. Penggunaan Metode Kooperatif Tipe STAD untuk Mengingkatkan Aktivitas dan Ketuntasan Belajar Siswa. Chemistry in Education Vol. 1 No. Ihttps://journal.unnes.ac.id/sju/index.php/chemined/article/view/6571

Usman. 2001. Upaya Optimalisasi Kegiatan Belajar Belajar Mengajar. Bandung: Remaja Rosdakarya.

Utam, S. 2015. Peningkatan Hasil Belajar Melalui Pembelajaran Kooperatif Tipe STAD Pada Pembelajaran Dasar Sinyal Video. Jurnal Pendidikan dan Kejuruan Vol. 22 No. 4 https://journal.uny.ac.id/index.php/jptk/article/view/7840/6712

Tipa, D.S.R. dkk. 2016. Penerapan Pembelajaran Kooperatif Tipe STAD (Student Team Achivement Division) Untuk Mengingkatkan Pemahaman Konsep Siswa Kelas VII Sekolah ABC Topik Relasi dan Fungsi. A Journal of Language, Literature, Culture, $\begin{array}{llllll}\text { adn Education } & \text { (POLYGLOT) } & \text { Vol. } & 12 & \text { No. } & 2\end{array}$ https://ojs.uph.edu/index.php/PJI/article/view/367/162 